\title{
Learner Identity Construction of EFL Postgraduate Students: A Narrative Case Study
}

\begin{abstract}
Ai Fatmawati ${ }^{1 *}$
${ }^{1}$ Universitas Pendidikan Indonesia

${ }^{*}$ Corresponding author.email: aifatma96@upi.edu

ABSTRACT

The learners of English as a foreign language commonly have a variety of linguistic and cultural background and the learning of a new language will influence how they construct their identity. The present narrative case study attempted to explore how English learning has shaped the learner identity of two Indonesian postgraduate students of English. Two participants, Hera and I, were included in this study. To collect the data, interview was conducted to gain Hera's stories about her identity construction journey, and autobiography narrative was used to describe mine. The data collected covered our reflections of several significant events in constructing our learner identity. The result was revealed through three themes: our learning experiences which covered our initial encounter with English, teaching approaches, and the challenges we found during English learning; source of motivation in learning; and cultural influence.
\end{abstract}

\section{Keywords: Learner identity, English language learners, Postgraduate students}

\section{INTRODUCTION}

Since learners of English come to the classroom with a variety of linguistic and cultural repertoires, they will have different, complex, and continuing negotiation of identities [1], [2]. Identity encompasses how one perceives oneself and how others view oneself, as well as how one puts oneself in regard to one's existing background (home culture) and the new settings (target culture) [3]. It seems identity has recently been an intriguing problem in second/foreign language study [4], [5]. García-Pastor [6] argues that it is unsurprising if education is seen as person shaping aimed to expand and perhaps in some ways modify learners' identity and the idea that language is a tool for learners' identity building.

The identity of language learner is perceived and theorized as multidimensional, a site of development and transformation, and changeable [7]. Exploring identity of learner becomes important because it influences or is an aspect of how humans make sense of the world and their experiences in it, including their interactions with texts (McCarthy \& Moje, 2002 as cited in [1]). What teachers need to understand is that learners have multiple and changing identities, rather than merely as people with English learning needs [1]. Due to the importance of identity in learning English, this study examines how the learning of English has shaped the learner identity of two Indonesian postgraduate students of English.

\subsection{Identity in Language Learning}

Norton [8] defines identity as "how a person understands his or her relationship to the world, how this relationship is constructed across time and space, and how the person understands possibilities for the future.". The concept of identity encompasses all parts of life, including the individual, social, cultural, and political, and encompasses a wide range of terminology and meanings [9]. Constructing an identity consists of negotiating meanings of our experiences as members of social communities [10].

Identity is never isolated, fixed, or stable; rather, it evolves and changes throughout time, and it includes methods of linking oneself to the world and to other people [11]. Gandana [9] summarizes Gomzina's theory 
of identity construction. It is explained that individuals seem to have a 'core'- a static element- while everything else around them is dynamic and constantly evolving, depending on the situation. These contexts, in turn, can give individuals with different interpretations of life as they engage with others, modifying their perspective of the world in a dynamic and continuous way. In addition, [5] suggests that mastery of foreign language should be "a bridge to explore the wider world and reflect on our own identity with more mature perspectives".

\subsection{Classroom interaction}

For students who do not see English being used in their community, they will find it only in the classroom through the school curriculum [12]. Since English in Indonesia is more likely to be taught and learned as foreign language, it can be understood that most English learning and teaching takes place in classroom rather than in everyday communication [13]. [14] viewed the classroom interaction as the primary setting for this process of language learners constructing their identities. It composes both the social context as well as the means by which the students develop their individual identities and struggle to re-create themselves within the community to which they belong: the community or EFL students.

A variety of approaches are implemented for teaching and learning a foreign language. Language teachers are charged for interpreting and applying language policies that affect their teaching methods. They are also in charge of transforming the national language policy into a school or classroom policy that is appropriate for the local context of teaching practice [15]. It can be understood that teachers play important role in providing a more active, free learning environment for the students to develop their positive attitudes towards English learning [16]. Students need to have wide exposure to English to be engaged in English discursive activities [12].

If teachers want the students to view themselves as proficient second language users in the future, or to ignite the vision and build an ideal second language self, teachers need to provide the students the ability to engage their current selves and identities in their second language interactions with others [17]. A variety of intrinsic and extrinsic motives influence the learning situation level. For instance, in extrinsic motives, courses are related to the curriculum, instructional materials, teaching technique, and learning tasks [18].

\subsection{Culture and Foreign Language Learning}

[19] asserts that "the term cultural has often been associated with the term 'social', as when one talks about the 'socio-cultural' factors affecting the teaching and the learning of foreign languages." Brown [20] argued that culture, as a rooted set of behaviors and patterns of perception, has a significant role in the acquisition of a second language. He stated that "a language is a part of a culture, and a culture is a part of a language: the two are intricately interwoven so that one cannot separate the two without losing the significance of either language or culture." It seems that learning a different language is the same as learning a different culture. It simply is the context for language use [21]. Lessard-Clouston [21] also argues that outside of the classroom, communicative skills, language, and culture continue to work together among L1 and L2 users. In addition, among the possible motivators, the desire to integrate with the culture of the language's speakers corresponds most closely with learning success [22].

As students grow up, they need to identify with something, and a large percentage of them select popular culture, which, since it is broadly available and widely accepted by young people, serves as a bond between them, offering meanings that are relevant to their life [23]. However, Prastiwi [24] noted that learners of English as a foreign language are suggested to study and accept the second culture as a knowledge rather than embracing and internalizing it as standards and values that apply to their daily lives.

\section{METHOD}

This study used narrative inquiry as the methodology. It focuses on how people use stories to make sense of their experiences to understand a phenomenon [25]. Hera (pseudonym) and I were the participants of the study. We are postgraduate students in the same university in Bandung. We both speak Sundanese but we come from different province. Hera lives in a big city named Bandung, West Java. She lives with a family with have a mixture of Sundanese and Bahasa Indonesia as their daily language. She studied in public schools for her primary, secondary, and graduate study. She started having exposure of English when she was in the fourth grade of primary school. I live in a small village in Brebes, Central Java. I studied in public primary school, and I enrolled in Islamic boarding school for my secondary study. I started having regular English class when I was in junior high school.

To gain the stories of Hera's experiences in learning English, interview was conducted lasting for about thirty-six minutes. To add some missing stories, the stories were also told through voice note WhatsApp. Meanwhile, I shared my experiences which I considered as the significant events in my identity construction in learning English through autobiographical narratives. Wirza [12] argues that individual narratives are one of the most powerful approaches to explore identity construction. 


\section{RESULT AND DISCUSSION}

This study examines how learning English shaped two Indonesian postgraduate students as a learner. The findings and discussions will be elaborated into three themes which are the English learning experience, motivational factors, and cultural influences.

\subsection{English Learning Experience}

Hera and I first met English when we were in primary school. My first initial encounter with English is when I was in primary school. English in my primary school was not taught regularly. I only learned it twice when I was in the sixth grade. Meanwhile, Hera started her first encounter with English when she was in the fourth grade of primary school. English in her primary school was not taught as a mandatory school subject, yet it was only local subject. She had hardly exposure with English in her environment before it. For example, when her parents sing lullaby, they had never sung English songs or read English stories. We both enjoyed our initial English classes. For me, the difference of the phonology and pronunciation between English and Indonesia created a big curiosity. I thought English sounded so good and cool. For Hera, she enjoyed learning English because she enjoyed the way her teacher taught.

"At that time, I did not know the role of English language in this globalized era, and I did not have any idea about the importance of learning another language. What made me love English at the first sight was because it sounded so cool and wonderful." (Ai)

"Usually, after we read some stories, the teacher would ask us to find some words in some paragraphs to be translated. We were required to bring dictionary. However, although she is not from English educational background, she is the one who made me realize that I like English since I really enjoyed the way she taught. I enjoyed translating words because the moment when I looked up in the dictionary and found the words and I wrote it on the book was the best moment of my life." (Hera)

In our secondary school, the teachers of Hera and I mostly taught us grammar. The teachers were the ones who led the learning situation. They did not encourage us to use the language. It is stated by [26] that when the teacher focuses on more grammatical rules, students will rarely get the opportunity to listen to and communicate in the target language.

In this era, we can find a lot of things related to English language and its culture such as music, movies, or stories easily. Hera and I enjoy its culture for both pleasure and fun English learning outside the classroom. It is relevant to what [23] stated that students need to identify with something as they grow up, and a significant proportion of them select popular culture, which, since it is widely available and widely accepted by young people, serves as a bond between them, providing meanings that are relevant to their life.

"Since I could not bring electronic items to Islamic boarding school, I rarely watched or listened to English movies or songs, but some of the teachers sometimes let us watch movies or used movies as the medium of the learning, or songs to practice students' listening. Movies or songs could cheer me up since it was a pleasure way in learning English. It is an amusement." (Ai)

"I like a music group named one direction which makes me want to learn English more. When they sing, of course they tell lyrics. So, I try to find out what the meaning is. I want to see the interview which means I should understand what they are saying. I also read a fan fiction in English. I need to find the meanings. That what makes me learn English again and again." (Hera)

During our English learning, we found some challenges. Both Hera and I perceive speaking as the challenge of our English learning. [27] view that one of the most challenging language skills for learners is speaking. One of the possible reasons is that speaking requires complex skills, not merely conveying ideas verbally. For me, what makes English is so difficult is related to my limited English practice. I had difficulties in finding partners to speak English. According to Wirza [12], from a pedagogical standpoint, learners with little exposure to English will have less possibilities to engage in English discursive activities that are required to build their identities as English learners and users.

"I realize that it is so difficult for me to find partner to speak English. Even when I was in my graduate study. I speak English only when I was in the classroom." (Ai)

Meanwhile, for Hera, what makes English a challenge in her English learning until now is because she needs to switch the language in her head. She thinks that English is not her language, so she has no sense of ownership of English. Hera and I had the same fear toward speaking English since I argue that speaking English needs a lot of courage and make us often feels anxious of making mistakes and judgements. [28] argues that it can be caused by students' perception regarding good English students who are like the idealized native speaker. It will arise a feeling of inadequacy and self-doubt because of the pressure. In addition, the finding of a study conducted by [29] revealed that students were more afraid of receiving a negative evaluation. It could be due to the cultural tradition, hating receiving low evaluations or criticism about themselves. 


\subsection{Motivational Factors}

Hera and I believe that learning English has given us benefits. For me, it was at my senior high school, when I got chosen to join a comparative study to abroad. That opportunity was given to students who learned and speak English for their daily activities. Being able to speak English helped me so much in that agenda. While for Hera, English helps her academic, social, and culture comprehension.

"Of course, basically English helps me understand the language itself. I can blend in with people from abroad. And learning English helps me understand different culture, respect their culture and implement some of them." (Hera)

The findings are supported by [30] who said young generation English learners perceive English as a critical tool for improving their lives, such as expanding work opportunities, earning money, becoming global citizens, communicating with foreigners, and gaining access to higher educational opportunities. Hera and I believe that motivation that we have is what makes us bear in learning English. What motivates me the most in learning English is the willing to speak like native speakers. I love their accent, so I want to speak like the way native speakers do. For me, speaking like native speakers is cool and will make the speaker look like an expert. It corroborates to the finding of the study conducted by Rini [31] that revealed talking like a native speaker elevates their social position and gives them a more distinct identity. It will also expand their network to more open career opportunities such as manager, businessman, and similar positions. Nevertheless, Sa'd [32] found that it is conceivable that I see myself as an outsider in the English domain and try to identify with the language norms to reduce the feeling of 'outsiderness'.

Meanwhile, for Hera, the role of teachers plays important role in motivating or demotivating her in learning English. She loved learning English at primary school because she liked the way her teacher taught, but she hates learning English in junior high school because she hated the way her teacher taught.

"When I was in the seventh grade, I was less motivated since I have enrolled in popular public junior high school and expected great qualities in English learning, but I did not get that. The English teacher asked us to memorize so many vocabularies in English. Within a week, as I recall, we must memorize 50-100 vocabularies. We also must memorize grammatical rules, Verb 1, Verb 2, and so on. and I don't like being forced to do that. When we don't memorize or remember it, he would punish us, asked us to stand up outside of the classroom until the class ended. It made me demotivated in learning English. Being early teenager back then, I was like hating English because I hated the teacher." (Hera)

The excerpt above is in accordance with what [18] have stated that teaching technique can be students' extrinsic motivation in learning. Besides teachers, she also gets motivated more in learning English when she got achievements as the acknowledgement from other people to her English competence.

"When I got accepted in my college through SBMPTN, I feel like the college acknowledge my English comprehension. Or when I got accepted to be the moderator of an international conference at my college. I joined the test without any preparation since I had lots of assignments, and I got accepted. And when I was graduated, I was announced as the best graduate student at my study department. And that was one of my motivation to continue my degree. Like, I still have many things to learn, and I have not had sufficient knowledge of English. " (Hera)

It is similar to what [33] said that students' positive experiences and achievements in foreign language learning influence their confidence and further motivates them in learning. It seems that Hera's learner identity is constructed through the teaching approaches the teacher used and the supports such as achievement or acknowledgment given from others.

\subsection{Cultural Influences}

We believe that when we learn a language, we also learn its culture since we believe that a language is a part of a culture. It is as what Brown [20] stated that "language is a part of a culture, and a culture is a part of a language." We perceive English and its culture as a cool and prestigious language. Hera believes that when we learn the culture of the language, we can get deeper meanings of the language and connected more with the native speakers. It corroborates with Scoon [22] has argued that the desire to engage with the culture of the language's speaker is the most possible motivators that can corresponds most closely with language learning success.

Hera and I felt some changes after we learn English. With or without our realization, how natives behave and think influence us as well. Some of the cultures are absorbed, some of them are not if the values are not relevant to what we have hold. It is in line with what Gandana [9] has summarized from Lin's (2014) explanation that when people use a particular language to interact with others, not only linguistic forms, but also values and ideologies are encoded, constituted, and embedded in the language which might alter one's sense of identity.

For me, English influences how I think which is different from how my family does. It opens my mind to the world. I acknowledge that it sometimes distorts my 
own cultural identity. However, the more I learn, the more I know that there are some values or beliefs that I cannot follow. It is in the excerpts below:

"I started to be aware that I cannot interfere other people business if I am not asked. I try to respect other privacy. As far as I know, western people are secularists. I think that is one of the ideologies that I cannot adopt since I'm a Muslim." (Ai)

"Of course, I acquired some cultures of western countries, yet there are some values that I don't accept. I start to be aware of other privacy. I now understand that there are so many things that I do not need to ask to other people, such as asking about income to my close friend or even strangers. I feel that is weird. I know that western people will not ask about other people's income." (Hera)

When we can select what values or beliefs we need and do not need to adopt, we use English as "a bridge to explore the wider world and reflect on our own identity with more mature perspective" [5]. In this era, English is used everywhere. As a result of globalization as a growing influencing force, English has become the world's lingua franca [34]. With the use of English in this globalized world, some instructions on how to do or install something using English only are often found. It makes Hera think that understanding English eases her life and her surroundings. For me, it is simply as eases me in understanding west movies or videos that do not have subtitle in Bahasa Indonesia.

However, despite the benefits Hera and I felt during learning English, we were aware of where we can or cannot use English. We have the similar perceptions that sometimes, in some phrases, it is nicer to express it using English than Bahasa Indonesia, yet we acknowledge that many of our friends still do not understand English much and the use of English for conversation in public place is still rare. It is pointed out by Onishi [35] and Pramono [36] that the practice of English in public places in Indonesia might be interpreted as a lack of nationalism and arrogance. It means we are aware of our identities as Indonesian [28].

\section{CONCLUSION}

From the findings above, it can be seen that Hera and I believe that learning English has a positive impact on our identity construction. We perceive English as a cool and prestigious language that provides us with many benefits. As an English learner, the way teacher taught influenced us in learning and understanding English.

From the story above, it can be seen that our English learning is implemented through form-focused and teacher-centered instruction that highlighted simple grammar, repetition, and memorization [37], [12]. That kind of learning process rarely encourage us to use the language which create limit speaking practice and incapable to communicate using it. It led us to the tension in learning English. However, it was also explored how I truly want to speak like native speaker, or the acknowledgment from others for Hera's English competence highly motivated us in learning English. As we learn English and its culture, we also learn what beliefs or values that we can or cannot adopt based on our religion and country. It indicates we are aware of our identities as Indonesian and also Muslims.

\section{AUTHOR'S CONTRIBUTIONS}

AF was responsible for designing the paper, carrying out the data collection and analysis, and drafting the manuscript. The author read and approved the final manuscript.

\section{ACKNOWLEDGMENTS}

I would like to thank my participant for giving her time to share her stories in learning English. Other than that, I would like to express my gratitude for Ibu Isti Gandana who have pushed me in finishing this paper.

\section{REFERENCES}

[1] S.M. Anwaruddin, Learner identity in second language education. In: Proceedings of 3L: Language, Linguistics, Literature, vol. 18, 2012, pp. 13-23.

[2] L. J. Choi, Embracing identities in second language learning: Current status and future directions, in: Proceedings of Problems of Education in the 21st Century, vol 76, 2018, pp. 800-815. DOI: https://doi.org/10.33225/pec/18.76.800

[3] C. Wang, Toward a second language socialization perspective: Issues in study abroad research, in: Proceedings of Foreign Language Annals, vol. 43, 2010, pp. 50-63. DOI: https://doi.org/10.1111/j.1944-9720.2010.01059.x

[4] Y. Gao, Z. Jia, Y. Zhou, Y, EFL learning and identity development: A longitudinal study in 5 Universities in China, in: Proceedings of Journal of Language, Identity and Education, vol. 14, 2015, 137-158. DOI: https://doi.org/10.1080/15348458.2015.1041338

[5] A. Lie, English and identity in multicultural contexts: Issues, challenges, and opportunities, in: Proceedings of TEFLIN Journal, vol. 28, 2017, 71-92. DOI: https://doi.org/10.15639/teflinjournal.v28i1/71-92

[6] M. D. García-Pastor, Learner identity in EFL: An analysis of digital texts of identity in higher 
education, in: Proceedings of Digital Education Review, 33, 2018, pp. 55-76. DOI: https://doi.org/10.1344/der.2018.33.55-76

[7] W. Huang, The EFL learner identity development: A perspective of metaphor, in: Proceedings of International Journal of Innovative Interdisciplinary Research, vol. 1, 2011, pp. 1-13.

[8] B. Norton, Identity and language learning: Gender, ethnicity, and educational change, Pearson Education, 2000.

[9] I. S. S. Gandana, Exploring third spaces, in: Proceedings of The International Journal of Diversity in Organizations, Communities, and Nations: Annual Review, vol. 7, 2008, pp. 143-150. DOI: $\quad$ https://doi.org/10.18848/14479532/cgp/v07i06/58032

[10] E. Wenger, Communities of practice: learning, meaning, and identity, Cambridge University Press, 1998.

[11] T.E. Lamb, Fragile identities: Exploring learner identity, learner autonomy and motivation through young learners' voices, in: Proceedings of Canadian Journal of Applied Linguistics / Revue Canadienne de Linguistique Appliquee, vol. 14, 2011, pp. 68-85.

[12] Y. Wirza, A narrative case study of Indonesian EFL learners' identities, in: Proceedings of Indonesian Journal of Applied Linguistics, vol. 8, 2018, pp. 473-481. DOI: https://doi.org/10.17509/ijal.v8i2.13313

[13] U. Sulistiyo, English language teaching and EFL teacher competence in Indonesia, in: Proceedings of the Fourth International Seminar on English Language and Teaching, vol. 4, 2016, pp. 396406.

http://ejournal.unp.ac.id/index.php/selt/article/vie $\mathrm{w} / 7001 / 5535$

[14] J. C. Gomez Lobaton, Language learners' identities in EFL settings: resistance and power through discourse, in: Proceedings of Colombian Applied Linguistics Journal, vol. 14, 2012, pp. 60. DOI. https://doi.org/10.14483/22487085.3813

[15] H. P. Widodo, Language policy in practice: Reframing the English language curriculum in the Indonesia secondary education sector, In Robert Kirkpatrick (Ed.), Proceedings of English language education policy in Asia, 2016, pp. 127151.

[16] M.N. Gömleksiz, An evaluation of student's attitudes toward English language learning in terms of several variables, in: Proceedings of Social and Behavioral Sciences, vol. 9, 2010, pp. 913-918. DOI:

\section{https://doi.org/10.1016/j.sbspro.2010.12.258}

[17] E. Ushioda, Language learning motivation, self and identity: Current theoretical perspectives, in: Proceedings of Computer Assisted Language Learning, 24(3), 2011, pp. 199-210. DOI: https://doi.org/10.1080/09588221.2010.538701

[18] A.P. Gilakjani, L. Leong, N.B. Sabouri, A study on the role of motivation in foreign language learning and teaching, in: Proceedings of International Journal of Modern Education and Computer Science, 7, 2012, pp. 9-16. DOI: https://doi.org/10.5815/ijmecs.2012.07.02

[19] C. Kramsch, The cultural component of language teaching. Language, Culture and Curriculum, vol. 8, 1995, pp. 83-92. DOI: https://doi.org/10.1080/07908319509525192

[20] H.D. Brown, Principles of language learning and teaching (2nd. ed.), Prentice-Hall, 1994.

[21] M. Lessard-Clouston, Chinese teachers' views of culture in their efl learning and teaching, in: Proceeding of Language, Culture and Curriculum, vol. 9(3), 1994, pp. 197-224.

[22] A.R. Scoon, Affective influences on English language learning among Indian students, in: Proceedings of TESOL Quarterly, vol. 5(4), 1994, pp. 285-291. DOI: https://doi.org/10.2307/3585494

[23] C. K. Cheung, The use of popular culture as a stimulus to motivate secondary students' english learning in Hong Kong, in: Proceedings of ELT Journal, vol. 55(1), 2001, pp. 55-61. DOI: https://doi.org/10.1093/elt/55.1.55

[24] Y. Prastiwi, Transmitting local cultural knowledge through English as foreign language (EFL) learning as a means of fostering "Unity in Diversity." Academic Journal of Interdisciplinary Studies, vol. 2(3), 2012, pp. 507-514. DOI: https://doi.org/10.5901/ajis.2013.v2n3p507

[25] G. Barkhuizen, B. Phil, C. Alice, Narrative inquiry in language teaching and learning research, Routledge, 2014.

[26] S. A. Manan, M.K. David, F. P. Dumanig, English language teaching in Pakistan: Language policies, delusions, and solutions. In Robert Kirkpatrick (Ed.), in: proceedings of English language education policy in Asia, 2016, pp. 127-151.

[27] M. Abrar, A. Mukminin, A. Habibi, F. Asyrafi, M. Makmur, L. Marzulina, "If our English isn't a language, what is it?" Indonesian EFL Student Teachers' Challenges Speaking English, The 
Qualitative Report, vol. 23(1), 2018, pp. 129145.DOI: https://doi.org/10.46743/2160$\underline{3715 / 2018.3013}$

[28] N.T. Zacharias, EFL students' understanding of their multilingual English identities, in: Proceedings of Electronic Journal of Foreign Language Teaching, 9(2), 2012, pp. 233-244.

[29] Z. Na, A study of high school students' English learning anxiety, in: Proceedings of The Asian EFL Journal, 9(3), 2007, pp. 22-34.

[30] Niño-Murcia, M. (2003). "English is like the dollar": Hard currency ideology and the status of English in Peru. World Englishes, 22(2), 121-141. https://doi.org/10.1111/1467-971X.00283

[31] Rini, J. E. (2014). English in Indonesia: Its position among other languages in Indonesia. Beyond Words, 2(2), 19-39.

http://journal.wima.ac.id/index.php/BW/article/vie $\mathrm{w} / 591$

[32] Sa'd, S. H. T. (2017). Foreign language learning and identity reconstruction : Learners' understanding of the intersections of the self, the other and power. C. E. P. S Journal, 7(4), 13-36.

[33] Bahous, R., Bacha, N., \& Nabhani, M. (2011). Motivating students in the EFL classroom: A case study of perspectives. English Language Teaching, 4(3), 33-43. https://doi.org/10.5539/elt.v4n3p33

[34] Safari, P., \& Razmjoo, S. A. (2016). An exploration of Iranian EFL teachers' perceptions on the globalization and hegemony of English. Qualitative Research in Education, 5(2), 136-166. https://doi.org/10.17583/qre.2016.1797

[35] Onishi, N. (2010, July 25). As English spreads, Indonesians fear for their language. New York Times. Retrieved from https://www.nytimes.com/2010/07/26/world/asia/ 26indo.html

[36] Pramono, B. (2009). Nasionalisme dan logat 'bule' indoglish [Electronic Version]. Retrieved from http://portal.sarapanpagi.org/sosialpolitik/nasionalisme-dan logatbuleindoglish.html

[37] Doro, K. (2007). The use of high- and lowfrequency verbs in English native and non-native student writing. In Z. Lengyel \& J. Navracsics (Eds.), Second language lexical processes: Applied linguistic and psycholinguistic perspectives (pp. 117-132). Multilingual Matters. 